\title{
Factors Influencing Uptake of Prostate Cancer Screening among Adult Males in Iseyin LGA, Oyo State
}

\author{
Olarewaju S.O' ${ }^{1}$ Akinola Amudat D², Oyekunle Emmanuel $O^{3}$, Adeyemo Sunday $C^{4}$
}

\begin{abstract}
Background: Prostate cancer (PCa) is the second leading cause of cancer-related death in the world. This study assessed factors influencing uptake of PCa screening at a popular town in Iseyin, Oyo State.
\end{abstract}

Methods: Relevant information was obtained from 376 participants using pre-tested semi-structured questionnaires. Respondents were selected through multistage sampling technique Statistical tests such as Chisquare, Fisher's exact test and Student's T-test were performed to duly analyse data obtained.

Results: Participants' mean age was $50.2 \pm 8.0$ years with a larger $(58.5 \%)$ proportion of men aged 50 and below. Overall summarized scores on poor knowledge and negative attitude were $42.8 \%$ and $44.7 \%$ respectively. Specific knowledge regarding location of prostate, risk factors and symptoms was as low as $21.0 \%$, $26.3 \%$ and $37.2 \%$, respectively. Barely $27.9 \%, 19.9 \%$ and $16.2 \% \mathrm{knew}$ prostate specific antigen test, digital rectal examination and ultrasound as PC screening techniques respectively. Previous uptake of screening was very low being $16.0 \%$. Individuals with poor knowledge and those who are non-professionals are 3 times (Odds Ratio - 0.295) and 2 times (Odds Ratio - 0.524) respectively less likely to do PCa screening compared with their other counterparts

Conclusion: The study showed considerable awareness of prostate cancer. However, comprehensive knowledge of its symptoms and the screening methods was greatly lacking. The need is therefore indicated for an aggressive health promotion intervention designed to increase awareness on PCa screening at the community level.

Keywords: prostate cancer, uptake, screening methods

\author{
*Corresponding Author \\ Dr Sunday Olarewaju \\ E-mail: sunday.olarewaju@uniosun.edu.ng \\ ${ }^{1}$ Department of Community Medicine, Osun-State University \\ ${ }^{2}$ Oyo State Hospital Health Management Board \\ ${ }^{3}$ Department of Radiology, University College Hospital, Ibadan \\ ${ }^{4}$ Public Health Department, Institut superiuer De Sante ( Higher institute of health) Niamey, Niger Republic
}

Received: June 21, 2020

Accepted: August 31, 2020

Published: December 31, 2020

Research Journal of Health Sciences subscribed to terms and conditions of Open Access publication. Articles are distributed under the terms of Creative Commons Licence (CC BY-NC-ND 4.0). (http://creativecommons.org/licences/by-nc-nd/4.0). 


\title{
Facteurs influant sur le dépistage du cancer de la prostate chez les hommes adultes à Iseyin, état d'Oyo
}

\author{
Olarewaju S.O ${ }^{1}$, Akinola Amudat D², Oyekunle Emmanuel $\mathbf{O}^{3}$, Adeyemo Sunday $\mathrm{C}^{4}$
}

\section{Résumé}

Objectifs de l'étude: Le cancer de la prostate $(\mathrm{CP})$ est la deuxième cause de décès par cancer dans le monde. Cette étude a évalué les facteurs influençant l'adoption du dépistage du CP dans une ville populaire d'Iseyin, dans l'état d'Oyo.

Méthode de l'étude: Des informations pertinentes ont été obtenues auprès de 376 participants à l'aide de questionnaires semi-structurés pré-tests. Les répondants ont été sélectionnés au moyen d'une technique d'échantillonnage à plusieurs degrés. Des tests statistiques tels que le chi carré, le test exact de Fisher et Étudiant (Student) T-Test) ont été effectués pour analyser correctement les données obtenues.

Résultats de l'étude: L'âge moyen des participants était de 50,2+8,0 ans avec une plus grande proportion $(58,5 \%)$ d'hommes âgés de 50 ans et moins. Les scores globaux résumés sur les connaissances insuffisantes et l'attitude défavorable étaient de $42,8 \%$ et $44,7 \%$ respectivement. Les connaissances spécifiques concernant l'emplacement de la prostate, les facteurs de risque et les symptômes étaient aussi faibles que $21,0 \%, 26,3 \%$ et $37,2 \%$, respectivement. À peine $27,9 \%, 19,9 \%$ et $16,2 \%$ connaissaient le test d'antigène spécifique de la prostate, l'examen rectal numérique et l'échographie comme techniques de dépistage PC. La participation antérieure au dépistage était très faible, soit 16,0\%. Les personnes ayant de faibles connaissances et celles qui ne sont pas des professionnels sont 3 fois (Odds Ratio - 0,295) et 2 fois (Odds Ratio - 0,524) respectivement moins susceptibles de faire un dépistage de l'APC par rapport à leurs homologues

Conclusion: L'étude a montré une sensibilisation considérable au cancer de la prostate. Cependant, une connaissance approfondie de ses symptômes et des méthodes de dépistage faisait grandement défaut. Le besoin est donc indiqué pour une intervention de promotion de la santé agressive conçue pour accrôitre la sensibilisation au dépistage du CP au niveau communautaire.

Mots-clés: Cancer de la prostate, adoption, méthodes de dépistageonctionnalité familiale, structure familiale, vaccin

\section{*Corresponding Author}

Dr Sunday Olarewaju

E-mail: sunday.olarewaju@uniosun.edu.ng

${ }^{1 .}$ Department of Community Medicine, Osun-State University
${ }^{2}$ Oyo State Hospital Health Management Board
${ }^{3}$ Department of Radiology, University College Hospital, Ibadan
${ }^{4}$ Public Health Department, Institut superiuer De Sante ( Higher institute of health) Niamey, Niger Republic

Received: June 21, 2020

Accepted: August 31, 2020

Published: December 31, 2020

Research Journal of Health Sciences subscribed to terms and conditions of Open Access publication. Articles are distributed under the terms of Creative Commons Licence (CC BY-NC-ND 4.0). (http://creativecommons.org/licences/by-nc-nd/4.0). 


\section{INTRODUCTION}

The prostate gland is one of the key anatomical structures in the male human body. It is a sex gland about the size of a walnut surrounding the neck of the bladder and urethra. According to the American Cancer Society (ACS), about 174,650 and 31,620 were estimated for new cases of prostate cancer (PCa) and deaths from the disease respectively in the United States for the year 2019 (1). Prostate cancer has become the topmost cancer in Nigerian men as it constitutes $11 \%$ of all male cancers occurring in men of ages 40-59 years (2).

Recent report by World Health Organization (WHO) shows that within a period of four years, deaths from PCa in Nigeria increased by almost 100 percent, killing 26 men daily, up from 14 men every day (3). In order to improve PCa survivorship, it is important for every man to know his risk of having the disease as well as the associated signs and symptoms (4).

The Health Belief Model (HBM) which is a theory of health behaviour was developed in the 1950 s by a group of United States Public Health (PH) service social psychologists who tried to explain why so few people were participating in programs to prevent and detect disease. It is a good model for addressing behaviours that evoke health concerns such as high-risk sexual behaviour, HIV and cancers (5). Since this time, the HBM has evolved to address $\mathrm{PH}$ concerns and has been applied to a broad range of populations and health behaviours. It proposes that a person's health-related behaviour depends on his or her perception in four critical areas namely the severity of a potential illness, susceptibility to that illness, the benefits of taking a preventive action, and the barriers to taking that action (5).

The knowledge about the possibility of developing prostate malignancy as a type of cancer begins with the identification of prostate as one of the organs in the human body that can be diseased. While awareness of cancer is generally on the increase in Nigeria malignancy of the breast, cervix, head and neck are the most commonly known types. As prostate cancer develops, many men do not experience striking symptoms at its early stages. Besides, many men who are in their 40 s and may require screening could have the notion that prostate cancer is only a health challenge for the very elderly. the significant role played by the organ in the reproductive process. Besides, morbidity in the prostate and any of the surrounding anatomical structures could arise from the management of a diseased prostate gland and subsequently bring about mortality. nical management of a diseased prostate. The aim of this work was therefore to assess the factors influencing uptake of prostate cancer screening at Iseyin Local Government Area of Oyo state, south-western Nigeria. This assessment would be useful in controlling the increasing incidence of the malignancy and the associated mortality rate via a timely use of the available screening methods within the locality. It is reasonable to take timely steps in preventing a diseased prostate than striving to manage it.

\section{METHODS AND MATERIALS}

\section{Study Area and Design}

Iseyin is one of the popular cities in Oyo state, Nigeria and about $100 \mathrm{~km}$ away from Ibadan the state's capital (6). It has an estimated population of 236,000 in 2005 and 302,990 in 2011 according to United Nations. Its chief industry deals in cottonbased textiles, and as such the city is popularly known as the Home of Aso-oke. Tobacco is primarily grown in Iseyin, amongst other food and cash crops, hence the presence of British American Tobacco company in the state (6). In addition, major agricultural activities include farming, hunting, fishing and food processing. Crops produced within the town include yam, maize, cassava, plaintain among others. (6).

\section{Study design}

This is a cross-sectional descriptive study design involving men residing in Iseyin Local Government Area (LGA) of Oyo. Exclusion criteria include males who are visitors of the LGA and those who are less than 34 years old.

\section{Sample size estimation}

The sample size was estimated using the Leslie Fisher's formula $\left(n=z^{2} p q / d^{2}\right)$ for prevalence studies (7) where $n=$ desired sample size, $z=$ the standard normal deviate set at 1.96 which correspond to $95 \%$ confidence level. An estimated sample size of 376 participants was determined based on a precision of 0.05 (5\% error margin) and a proportion (p) of $43 \%$ from a previous study on awareness and knowledge of PCa among men in another part of Nigeria. 


\section{Sampling technique}

Multi-stage sampling technique was used. Through simple random sampling (SRS), 5 wards were chosen from the list of 10 wards in local government (LG) area. The list of all enumerated areas in the selected wards were then obtained from the LG council headquarters. Households were selected by SRS while the final respondents were recruited from selected households based on SRS until the required sample size is obtained.

\section{Study Instruments}

\section{Semi-structured questionnaire}

A semi-structured questionnaire was used as the survey instrument. This was designed to seek information about the respondents' sociodemographic characteristics, knowledge of prostate cancer and its screening methods and other related information. The research assistants recruited were community health extension workers in Iseyin LGA. A two-day orientation (training) of the research assistants was done on how to fill the contents of the questionnaires before final commencement of data collection to ensure uniformity.

\section{Pre-testing of Research Instrument}

The validity of the research instrument was done by pre-testing the tools among men in Afijio LG area outside the study area. This helped to know whether or not the questionnaire measures what it is intended to measure with respect to the purpose of the study. It also served to address any form of ambiguity in the questionnaire.

\section{Data Collection and Management}

Questionnaires were sorted out to check for errors and omissions at the end of data collection. Analysis was performed with Statistical Package for Social Sciences (SPSS) version 20. Frequency distribution tables, charts and graphs were generated from variables while cross tabulation and test statistics were done where applicable. Chi-square was used to compare rates, ratios and proportions while Fisher's exact test was used with cells that have expected values less than 5 . Student's T-test was also done at a p-value less than 0.05 .

\section{Measurement of outcome variables}

Questions about knowledge and attitude were scored. For questions with responses as yes or no, a correct and a wrong answer were scored as 1 and 0 respectively. Questions with three responses being Yes, No and I don't know) were scored 2, 1 and 0 if correct, no idea and wrong answers were given respectively. For questions on attitude that had strongly agree, agree, indifferent, disagree and strongly disagree options, the response was scored $5,4,3,2,1$ respectively for a positive attitude and $1,2,3,4,5$ for a negative attitude. Maximum scores together with mean scores for knowledge and attitude were computed. Respondents who scored below the mean value were regarded as having poor knowledge or negative attitude as the case may be. On the other hand, those who scored up to or above mean values were considered to have good knowledge or positive attitude.

\section{Ethical consideration}

Ethical approval was obtained from the ethical committee of the Ladoke Akintola University Teaching Hospital, Ogbomoso and permission was obtained from community leaders. Verbal consent was obtained from all respondents before the questionnaires were administered. Anonymity and confidentiality of information collected was assured while participation was voluntary.

\section{Limitation of the study}

The limitation of the present study is its confinement to a part of the ancient Oyo state due to constraints in time and resources. Nevertheless, the resulting outcomes are in consonance with previous studies of wider geographical and sample coverage in the country. The present study could as well inform the need for subsequent work of this nature in different regions of the country and among different occupational groups. 


\section{RESULTS}

Men aged 50 and below constituted a larger (58.5\%) group of the study population than those older (41.5 $\%)$ as presented in Table 1 . Majority $(94.7 \%)$ were educated to varying degrees but the proportion of professionals is slightly above one-quarter $(26.6 \%)$ of the study population. This largely correlates with men $(30.3 \%)$ educated up to the tertiary level. Table 2 shows the participants were largely $(91.6 \%)$ aware of prostate cancer as a health challenge while only 37.2 $\%$, 26. $3 \%, 21 \%$ and $3.7 \%$ recognized urinary retention, inadequate urine, painful micturition and bloody urine as it symptoms. While many $(68.1 \%)$ believed that the disease is curable, a good number $(42 \%)$ did not know that it could be inherited. Table 3 presents attitude and beliefs on PCa screening. While one-third did not see the need for screening after age
45 , at least $27.6 \%$ considered usage of herbs as an effective treatment method. The overall summarized scores on knowledge and attitude are shown in Fig. 1 In figure 2, proportion (less than one-fifth) of study participants ever screened for $\mathrm{PCa}$ is given. Figures $3 \mathrm{a}, 3 \mathrm{~b}$ and $3 \mathrm{c}$ respectively reveal the timeline, techniques and outcomes of $\mathrm{PCa}$ screening. According to Table 4, there is significant $(\mathrm{P}<0.05)$ difference in occupation, categorized knowledge and attitude with previous screening practices. After controlling for cofounding effect in Table 5, analysis showed that non-professionals are two times less likely to do PCa screening compared to professionals. Also, participants with poor knowledge are three times less likely to embrace screening relative to those with good knowledge.

Table 1: Socio-Demographic Characteristics

\begin{tabular}{|c|c|c|}
\hline Variable & Frequency & Percentage \\
\hline \multicolumn{3}{|l|}{ Age groups } \\
\hline $34-39$ & 5 & 1.3 \\
\hline $40-45$ & 132 & 35.1 \\
\hline $46-50$ & 83 & 22.1 \\
\hline $51-55$ & 59 & 15.7 \\
\hline $56-60$ & 50 & 13.3 \\
\hline $61-65$ & 32 & 8.5 \\
\hline$>65$ & 15 & 4.0 \\
\hline \multicolumn{3}{|l|}{ Ethnicity } \\
\hline Yoruba & 318 & 84.6 \\
\hline Igbo & 32 & 8.5 \\
\hline Hausa & 26 & 6.9 \\
\hline \multicolumn{3}{|l|}{ Religion } \\
\hline Christianity & 261 & 69.4 \\
\hline Islam & 108 & 28.7 \\
\hline Traditional & 7 & 1.9 \\
\hline \multicolumn{3}{|c|}{ Educational level } \\
\hline Primary & 76 & 20.2 \\
\hline Secondary & 166 & 44.1 \\
\hline Tertiary & 114 & 30.3 \\
\hline None & 20 & 5.3 \\
\hline \multicolumn{3}{|l|}{ Occupation } \\
\hline Traders & 70 & 18.6 \\
\hline Artisans & 202 & 53.7 \\
\hline Professionals & 100 & 26.6 \\
\hline *Others & 4 & 1.1 \\
\hline
\end{tabular}

*Others represent adult men who were not engaged in any form of work 
Table 2: Findings about knowledge, risk factors, symptoms and screening methods for prostate cancer

\begin{tabular}{llc}
\hline Variable & Frequency & \% \\
\hline Recognition of PCa as a disease & 344 & 91.5 \\
Recognition of PCa as a curable disease & 256 & 68.1 \\
Consideration of PCa as a hereditary disease & 218 & 58.0 \\
Recognition of PCa as a disease for both gender & 92 & 24.5 \\
Recognition of PCa as a disease in all age groups & 73 & 19.4 \\
Having a belief that it can spread through sexual intercourse & 40 & 10.6 \\
Alcohol consumption as a risk factor for PCa & 340 & 90.4 \\
Cigarette smoking as a risk factor for PCa & 306 & 81.4 \\
Obesity as a risk factor for PCa & 256 & 68.1 \\
High intake of fatty food as a risk factor for PCa & 225 & 59.8 \\
Urinary retention as a symptom of PCa & 140 & 37.2 \\
Inadequate urine as a symptom of PCa & 99 & 26.3 \\
Painful micturition as a symptom of PCa & 79 & 21.0 \\
Bloody urine as a symptom of PCa & 14 & 3.7 \\
Knowledge of the availability of screening procedures for PCA & 252 & 67.0 \\
Recognizing early detection and treatment as benefits of screening & 214 & 56.9 \\
Identification of PSA blood test as a screening method for PCa & 105 & 27.90 \\
Identification of digital rectal examination as a screening method & 75 & 19.9 \\
Identification of TRUS as a screening method for the disease & 61 & 16.2 \\
Screening methods as preventable means against late complication & 50 & 13.3 \\
Screening methods as preventable means against untimely death & 27 & 7.2 \\
\hline
\end{tabular}

${ }^{*} \mathrm{PCa}$ is Prostate Cancer

Table 3: Attitude to Prostate cancer screening and treatment methods

\begin{tabular}{llllll}
\hline Variable & ${ }^{*}$ SA & ${ }^{*} \mathbf{A}$ & ${ }^{*}$ NS & ${ }^{*} \mathbf{D}$ & ${ }^{*}$ SD \\
\hline $\begin{array}{l}\text { PCa screening could avert early deaths } \\
\text { attributable to prostate cancer }\end{array}$ & 286 & 81 & 7 & 2 & 0 \\
PCa screening services are not necessary for & $(76.1 \%)$ & $(21.5 \%)$ & $(1.9 \%)$ & $(0.5 \%)$ & $(0 \%)$ \\
men above 45 years & $(6.6 \%)$ & 20 & 81 & 144 & 106 \\
$\begin{array}{l}\text { Removal of prostate gland after cancer } \\
\text { detention affects sexual function }\end{array}$ & 27 & $49.3 \%)$ & $(21.5 \%)$ & $(38.3 \%)$ & $(28.2 \%)$ \\
$\begin{array}{l}\text { Prostate Cancer can be treated effectively with } \\
\text { herbs }\end{array}$ & $(7.2 \%)$ & $(13 \%)$ & $163(43.4 \%)$ & 91 & 46 \\
& $(16.2 \%)$ & $43(11.4 \%)$ & 91 & $(24.2 \%)$ & $(12.2 \%)$ \\
\end{tabular}

"SA is Strongly Agree, ${ }^{*} \mathrm{~A}$ is Agree, ${ }^{*} \mathrm{NS}$ is Not sure, ${ }^{*} \mathrm{D}$ is Disagree, ${ }^{*} \mathrm{SD}$ is Strongly Disagree

Table 4: Overview of summarized scores on knowledge and attitude with timeline, techniques and outcomes of Prostate Cancer screening

\begin{tabular}{|c|c|c|c|c|}
\hline \multirow{2}{*}{$\begin{array}{l}\text { Evaluated } \\
\text { Parameters }\end{array}$} & \multicolumn{3}{|c|}{ Outcomes } & \multirow[t]{2}{*}{ Total } \\
\hline & \multicolumn{2}{|l|}{ Good } & Poor & \\
\hline Knowledge & \multicolumn{2}{|l|}{$215(57.2 \%)$} & $161(42.8 \%)$ & \multirow{11}{*}{$376(100 \%)$} \\
\hline \multirow[b]{2}{*}{ Attitude } & \multicolumn{2}{|l|}{ Positive } & Negative & \\
\hline & \multicolumn{2}{|l|}{$208(55.3 \%)$} & $168(44.7 \%)$ & \\
\hline \multirow{8}{*}{$\begin{array}{l}\text { Prostate Cancer } \\
\text { Screening }\end{array}$} & \multicolumn{2}{|l|}{ Screened } & Never-Screened & \\
\hline & \multicolumn{2}{|l|}{$60(16 \%)$} & \multirow[t]{7}{*}{$(84 \%)$} & \\
\hline & $\begin{array}{l}<5 \text { years ago } \\
>5 \text { years ago } \\
\end{array}$ & $\begin{array}{l}18(30 \%) \\
42(70 \%) \\
\end{array}$ & & \\
\hline & Transrectal Ultrasound & $13(21.7 \%)$ & & \\
\hline & $\begin{array}{l}\text { Digital rectal } \\
\text { Examination }\end{array}$ & $17(28.3 \%)$ & & \\
\hline & *PSA Test & $30(50 \%)$ & & \\
\hline & Positive & $18(30 \%)$ & & \\
\hline & Negative & $42(70 \%)$ & & \\
\hline
\end{tabular}

"PSA is Prostate Specific Antigen 
Table 5: Association between socio-demographic characteristics, summarized knowledge and attitude to prostate cancer screening.

\begin{tabular}{|c|c|c|c|c|c|c|}
\hline Variable & & Yes & No & 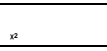 & df & $\mathbf{p}$ \\
\hline \multirow[t]{7}{*}{ Age (years) in categories } & $34-39$ & $2(40 \%)$ & $3(60 \%)$ & 12.05 & 6 & 0.061 \\
\hline & $40-45$ & $29(22 \%)$ & $103(78 \%)$ & & & \\
\hline & $46-50$ & $6(7.2 \%)$ & $77(92.8 \%)$ & & & \\
\hline & $51-55$ & $8(13.6 \%)$ & $51(86.4 \%)$ & & & \\
\hline & $56-60$ & $9(18 \%)$ & $41(82 \%)$ & & & \\
\hline & $61-65$ & $3(9.4 \%)$ & $29(90.6 \%)$ & & & \\
\hline & $>65$ & $3(20 \%)$ & $12(80 \%)$ & & & \\
\hline \multirow[t]{3}{*}{ ethnicity } & Yoruba & $48(15.1 \%)$ & $270(84.9 \%)$ & 1.2 & 2 & 0.54 \\
\hline & Igbo & $7(21.9 \%)$ & $25(78.1 \%)$ & & & \\
\hline & Hausa & $5(19.2 \%)$ & $21(80.8 \%)$ & & & \\
\hline \multirow[t]{3}{*}{ religion } & Christianity & $43(16.5 \%)$ & $218(83.5 \%)$ & 4.5 & 2 & 0.11 \\
\hline & Islamic & $14(13.0 \%)$ & $94(87.0 \%)$ & & & \\
\hline & Traditional & $3(42.9 \%)$ & $4(57.1 \%)$ & & & \\
\hline \multirow[t]{4}{*}{ level of education } & Primary & $8(10.5 \%)$ & $68(89.5 \%)$ & 6.97 & 3 & 0.07 \\
\hline & Secondary & $30(18.1 \%)$ & $136(81.9 \%)$ & & & \\
\hline & Tertiary & $22(19.3 \%)$ & $92(80.7 \%)$ & & & \\
\hline & None & $0(0.0 \%)$ & $20(100.0 \%)$ & & & \\
\hline \multirow[t]{4}{*}{ occupation } & Trading & $17(24.3 \%)$ & $53(75.7 \%)$ & 21.1 & 3 & $<0.01$ \\
\hline & Artisan & $16(7.9 \%)$ & $186(92.1 \%)$ & & & \\
\hline & Professional & $26(26 \%)$ & $74(74 \%)$ & & & \\
\hline & Others & $1(25 \%)$ & $3(75 \%)$ & & & \\
\hline \multirow[t]{2}{*}{ Categorized knowledge } & Good knowledge & $49(22.8 \%)$ & $166(77.2 \%)$ & 17.5 & 1 & $<0.01$ \\
\hline & Poor knowledge & $11(6.8 \%)$ & $150(93.2 \%)$ & & & \\
\hline \multirow[t]{2}{*}{ Categorized attitude } & Positive attitude & $42(20.2 \%)$ & $166(79.8 \%)$ & 6.23 & 1 & 0.01 \\
\hline & Negative attitude & $18(10.7 \%)$ & $150(89.3 \%)$ & & & \\
\hline
\end{tabular}

Table 6: Predictors of Previous uptake of Prostate Cancer Screening

\begin{tabular}{llcc}
\hline & Adjusted Odds ratio & $\mathbf{9 5 \%}$ interval & * p-value \\
\hline $\begin{array}{l}\text { Occupation } \\
\text { Professionals } \\
\text { Non-professionals }\end{array}$ & 1 & & \\
& 0.524 & $0.286-0.959$ & $\mathbf{0 . 0 3 6}$ \\
$\begin{array}{l}\text { Summarized knowledge } \\
\text { Good knowledge }\end{array}$ & 1 & & \\
Poor knowledge & 0.295 & $0.144-0.607$ & $\mathbf{0 . 0 0 1}$ \\
\hline
\end{tabular}

*P-value is the level of significance at $95 \%$ confidence interval

\section{DISCUSSION}

The risk of having prostate cancer rises rapdly after age 50 (9). The lower proportion (41.5\%) of study participants older than 50 as compared with the younger group could be attributed to the calibre of men available at the study area. Besides, it was needful to involve as many younger men as possible in order to assess their levels of knowledge on prostate cancer and participation in the screening practices. Consequently, the participants following completion of the research questionnaires got more enlightenment on the issues of interest. This act of sensitization would be greatly beneficial to their health in the long run.

Majority $(72.3 \%)$ of the men involved in the study were either engaged in trading or working as artisans. This is against the background that the study area is in a business-oriented city with its primary industry being cotton-based textiles. This is in addition to the easier accessibility of the research materials to the artisans than their other counterparts (professionals).

Participants who were aware of PCa was largely considerable (91.5\%) according to Table 2. This is justified given that approximately $95 \%$ (Table 1 ) had 
at least a primary education, and could therefore have read about the disease. The number of professionals is slightly above a quarter of the participants which to a large extent justified the low uptake of screening found. Men are most susceptible to prostate cancer, just as women are to breast cancer. Our study (Table 2) showed that almost half ( $42 \%$ ) of the respondents had the wrong notion that the disease cannot be inherited. Also, about one-quarter (24.5\%) believed it can develop in both male and female. The later finding is not strange considering a previous study (10) among the male staff of a university in a different part of Nigeria which revealed that a very high proportion $(84.7 \%)$ thought $\mathrm{PCa}$ occurs in females. This misconception which could have adverse implications on their attitude to PC screening therefore calls for correction within and outside the study community. The poor level of knowledge on screening techniques could be attributed to low proportion $(30.3 \%)$ of participants with tertiary degree or greater, most of whom are expected to assume good professional status in occupation. Winterich et. al (11) earlier reported that men's knowledge about the DRE and PSA increased with education, even though knowledge of PC symptoms was not associated with educational attainment. In relation to respondents' belief and attitude to prostate cancer screening, one-third (33. $4 \%$ ) did not see a need for screening after age 45 and at least $27.6 \%$ considered use of herbs as an effective treatment method. The levels of poor knowledge and negative attitude further obtained in our study (Table 4) are still considerable and calls for appropriate actions. The knowledge and awareness especially among adult males of age 40 and above about the importance of prostate cancer screening will determine whether or not they would consider the related available methods.

Screening refers to testing to find a disease such as cancer in people who do not have symptoms of that disease. American cancer society stated that for some types of cancer, screening can help find cancers at an early stage, when they are more easily cured (12). Research data from Tyrol, Austria, where free PSA screening policy was implemented for men of ages 45-74 years resulted in a 30\% screening-related decline of PCa mortality $(13,14,15)$. Our study participants (Table 2) agreed to this need accordingly as over half (56.9\%) of them recognized early detection and treatment as benefits of PCa screening. The studies by Bartsch et. al (16) and Horninger et. al (17) revealed that survival rates of men who engaged in PC screening and treatment were enhanced compared to those who did not undergo screening. While majority $(91.5 \%)$ were already aware of $\mathrm{PCa}$, occupation plays a crucial role in responsiveness to screening which is determined by a demonstration of positive attitude and ability to pay out of pocket for diagnostic investigations. This finding is supported by a previous study (11) in which $75.6 \%$ of male staff at a tertiary institution who had positive attitude to screening for $\mathrm{PCa}$ was academic staff. The study found a significant difference $(\mathrm{P}<0.05)$ between occupation and knowledge of respondents on prostate cancer, as well as between knowledge and acceptance of prostate cancer screening. Individuals with poor knowledge of symptoms, risk factors and screening methods for PCa are 3 times less likely to do screening compared to their counterparts with good knowledge. Similarly, men who are nonprofessionals are 2 times less likely to do screening for PCa compared to professionals (Table 6). The real cause of prostate cancer is unknown, and as such becomes difficult to ultimately prevent the disease. The risk factors such as those presented in Table 2 can however be controlled through appropriate public enlightenment to lower the risk of prostate cancer. While many of the men in our study were aware of some risk factors, identification of the related disease symptoms was is low. This could have also contributed to the low (16\%) uptake of screening techniques obtained in the present study.

The recommended age by the American Urological Association for PSA testing was reduced to 40 years because measurement for PSA level is more specialised for younger than older men (18) Men of ages 40 and above formed $98.7 \%$ (371) of our study population. Considering that there are no glaring symptoms for early prostate cancer, early detection should be prompted in 'at-risk' men, in this case Nigerian men (19). Again, the risk of developing prostate cancer will normally increase with the aging process. The ACS had recommended age 50 for commencement of prostate cancer screening for men who are at average risk of prostate cancer. (20). Age is the first risk factor to consider for PCa (21). Based on our results (Table 2), this knowledge was not duly demonstrated by our study participants. From the foregoing and the data on age distribution (Table 1), 156 - 371 men representing 41.5 - $98.7 \%$ should have been tested for PCa using any of the screening methods (Table 4). But the statistics in Table 4 showed that barely 60 men (16\%) had been screened for prostate cancer prior to the present study. This could be attributed to a combination of factors ranging from wrong beliefs, poor knowledge on the 
likelihood of $\mathrm{PCa}$ and the screening methods available as well as negative attitude found in many of the men (Tables 2 - 4.). Previous studies in Nigeria had shown a low level of prostate cancer awareness (22 -24). Table 5 focuses on uptake of PCa screening in relation to socio-economic and other related variables. It depicts the influence of education, occupation, categorized knowledge and attitude on participation in the screening procedures. Of the 60 men who had been previously screened, all (100\%) are educated, while majority are professionals (43 $\%$ ), of adequate knowledge $(81.7 \%)$ and of favourable attitude $(70 \%)$, and there is a statistically significant association between each and PC screening $(<0.05)$. Medical doctors could as a matter of health policy counsel men above 40 years of age seeking medical consultation on any health challenge to embrace $\mathrm{PCa}$ screening as part of their periodic medical check-up. This would be a good approach towards engaging more men in undertaking screening whether or not they present symptoms of the disease.

Since PSA testing has become regularly available, more men had been diagnosed with potentially curable localised PCa and at an age where radical local treatment is appropriate (25). While many could undergo radical prostatectomy or external beam conformal radiotherapy, some with localized $\mathrm{PCa}$ would be suitable for brachytherapy which is effective with relatively low morbidity. Screening men for prostate cancer was found to reduce mortality rates by about half in a large study (26). The best approach to treating it successfully is detection at an early stage, especially for men with an aggressive PCa. Research suggests that there is a general lower uptake of cancer screening among blacks and ethnic groups. Some identified barriers include religious beliefs, language barrier, illiteracy, poor health education, misconceptions about perceived risk and symptoms, lack of knowledge about services, and negative attitudes of health personnel (27). The findings in our study have supported some of these factors which should be borne in mind while accentuating efforts towards controlling the trend of PCa incidence and the associated mortality rate.

\section{CONCLUSION}

Our study demonstrated a reasonable level of awareness on the existence of prostate cancer among men at Iseyin local government area of Oyo state. Comprehensive knowledge regarding identification of prostate cancer symptoms, major risk factors and screening methods was however low. Poor knowledge of the above, occupation and negative attitude were found to be the most important factors influencing uptake of prostate cancer screening in the study population. These outcomes have therefore informed the need for a continuous dissemination of comprehensive information on $\mathrm{PCa}$ and screening techniques within various communities via the mass media. This would engender demonstration of the required behaviour by individuals whether or not professionals, who would thereafter readily agree to being tested with a consequent reduction in $\mathrm{PCa}-$ related mortality rate. Prostate cancer awareness and diagnostic services should also be readily available at all tertiary health facilities with the support of government and all stakeholders.

\section{ACKNOWLEDGEMENTS}

Authors sincerely acknowledge the support of community stakeholders towards the successful conduct of this study.

Conflict of interest: The authors declare no conflicts of interest.

\section{REFERENCES}

1. Key Statistics for Prostate Cancer. American Cancer Society. Available at: https://www.cancer.org/ cancer/prostate-cancer/about/key-statistics.html Accessed on September 10, 2019.

2. Achebe and Victoria H Robbinson. Prostate cancer and blackmen. 2018. Available at: http://nigeria villagesquare.com/articles/chidiachebe/prostate cancer and black-men-a-call-to-action Accessed on September 5, 2019.

3. Raphael NO. Review of Prostate Cancer in Nigeria. Journal of Health Sciences and Nursing. 2016; 1 (12).

4. Kemi Ajumobi. Safeguarding Nigerian men from the scourge of prostate cancer. Business Day Newspaper. September 12, 2014 Available at: https://businessday.ng/science/article/safeguardingnigerian-men-from-the-scourge-of-prostate-cancer/ Accessed on September 9, 2019.

5. Croyle RT. The health belief model. 2005 www.hbm/croyle/health.

6. Iseyin. Available at https://en.wikipedia.org/wiki/ Iseyin Accessed on September 14, 2019.

7. Katz DL, Elmore JG, Wild DMG, Lucan SC. Jekel's Epidemiology, Biostatistics, Preventive Medicine 
and Public Health. 4th ed. Philadelphia: Saunders; 2014. 153-162

8. Agbugui JO, Obarisiagbon EO, Nwajei CO, Osaigbovo EO, Okolo JC, Akinyele AO. Awareness and knowledge of prostate cancer among men in Benin City, Nigeria. Journal of Medicine and Biomedical Research. 2013; 12 (2): 42-47.

9. Prostate Cancer Risk Factors. Available at:https://www.cancer.org/cancer/prostatecancer/causes-risks-prevention/risk-factors.html Accessed on September 3, 2019

10. Adibe MO, Aluh DO, Isah A, Anosike C. Knowledge, Attitudes and Perceptions of Prostate Cancer among Male Staff of the University of Nigeria. Asian Pac J Cancer Prev. 2017;18(7): 1961-1966. Julie A. Winterich

11. Joseph G. Grzywacz, Sara A. Quandt, Peter E. Clark, David P. Miller, Joshua Acuña, BS, et al. Men's knowledge and beliefs about prostate cancer: education, race, and screening status." Ethnicity \& disease. 2009; 19 (2) 199-203.

12. Cancer Facts and Figures 2019. American Cancer Society. http://www.cancer.org/content/dam/cancer$\mathrm{org} / \mathrm{research} /$ cancer-facts-and-statistics/annualcancer-facts-and-figures/2019/cancer-facts-andfigures-2019.pdf

13. Oberaigner W, Horninger W, Klocker H, Schonitzer D, Stuhlinger W, Bartsch G. Reduction of prostate cancer mortality in Tyrol, Austria, after introduction of prostate-specific antigen testing. Am J Epidemiol. 2006;164(4):376-84

14. Oberaigner W, Siebert U, Horninger W, Klocker H, Bektic J, Schafer G, et al. Prostate-specific antigen testing in Tyrol, Austria: Prostate cancer mortality reduction was supported by an update with mortality data up to 2008. Int J Public Health. 2012;57 (1):57-62.

15. Horninger W, Berger A, Pelzer A, Klocker H, Oberaigner W, Schonitzer D, et al. Screening for prostate cancer: Updated experience from the Tyrol study. Can J Urol. 2005;12(Suppl 1):7-13.

16. Bartsch G, Horninger W, Klocker H, Reissigl A, Oberaigner W, Schönitzer D, et al. Prostate cancer mortality after introduction of prostate-specific antigen mass screening in the Federal State of Tyrol, Austria. Urology. 2001;58(3):417-424. doi: 10.1016/S0090-4295(01)01264-X.

17. Horninger W, Berger A, Pelzer A, Klocker H, Oberaigner W, Schönitzer D, et al. Screening for prostate cancer: updated experience from the tyrol study. Current Prostate Reports. 2005;3(1):5-10. doi: 10.1007/s11918-996-0009-9.

18. The Greene KL, Albertsen PC, Babaian RJ, Carter BH, Gann PH, Han M, et al. Prostate Specific Antigen Best Practice Statement: 2009 Update. American Urological Association. 2009;182(5) :2232-2241. doi: 10.1016/j.juro. 2009.07.093.

19. Odedina FT, Scrivens J, Emanuel A, LaRose-Pierre M, Brown J, Nash RA. Focus Group Study of Factors Influencing African-American Men's Prostate Cancer Screening Behaviour. J Natl Med Assoc. 2004; 96(6):780-788.

20. American Cancer Society Recommendations for Prostate Cancer Early Detection https://www. cancer.org/cancer/prostate-cancer/early-detection/ acs-recommendations.html Accessed on August 12, 2019.

21. Leslie SW, Soon-Sutton TL, Sajjad H, et al. Prostate Cancer. [Updated 2019 Oct 8]. In: StatPearls [Internet]. Treasure Island (FL): StatPearls Publishing; 2019 Jan-. Available from: https://www. ncbi.nlm.nih.gov/books/NBK470550/

22. Ajape AA, Babata A, Abiola OO (2010) Knowledge of prostate cancer screening among native African urban population in Nigeria. Nig Q J Hosp Med 20(2):94-96

23. Ogundele SO, Ikuerowo SO (2015) A survey of the awareness of prostate cancer and its screening among men attending the outpatient clinics of a tertiary health center in Lagos, Nigeria. Niger J Surg Off Publ Niger Surg Res Soc 21(2):115-118

24. Atulomah NO, Olanrewaju MF, Amosu AM, Adedeji O (2010) Level of awareness, perception and screening behavior regarding prostate cancer among men in a rural community of Ikenne Local Government Area, Nigeria

25. Shahyad S, Saadat SH, Hosseini-Zijoud SM. The Clinical Efficacy of Prostate Cancer Screening in Worldwide and Iran: Narrative Review. World J Oncol. 2018;9(1):5-12. doi:10.14740/wjon1082w

26. Prostate Cancer News: Prostate Cancer Screening: Benefits Outweigh Risks. https://www.webmd. com/prostate-cancer/news/20100701/prostatecancer-screening-benefits-outweigh-risks\#1

27. Thomas VN, Saleem T, Abraham R. Barriers to effective uptake of cancer screening among Black and minority ethnic groups. Int J Palliat Nurs. 2005; 11(11): 562, 564-71. doi: 10.12968/ijpn.2005.1 1.11 .20096 